\title{
ADIKSI INTERNET DAN KETERAMPILAN KOMUNIKASI INTERPERSONAL PADA REMAJA
}

\section{Internet Addiction and Interpersonal Communication Skills of Adolescents}

\author{
Pradinata Kusumo $^{1}$, Devi Jatmika ${ }^{2}$ \\ 1), 2)Program Studi Psikologi Universitas Bunda Mulia \\ Diterima 10 April 2020/ Disetujui 22 Juli 2020
}

\begin{abstract}
The use of the internet has been very widespread in today's life, almost every individual has access to use the internet. However, within certain limits the use of the internet that should be positive can turn into negative because of the effects of addiction. In previous studies have obtained results about the comorbidity of Internet addiction with depression, social problems, and anxiety. Excessive use of the internet can affect one's interpersonal skills. While at present, communication becomes an important thing in human life, especially for teenagers who are still at the stage of development. This study aims to determine the relationship between internet addictive with interpersonal communication relationships in adolescents. This research uses quantitative method. Subjects in this study are 400 adolescents aged $15-$ 19 years old in Jakarta. The sampling technique was purposive sampling technique. In this study the internet is measured using an Internet Addiction Test by Young, with reliability of 0.819 and interpersonal measurements using interpersonal communication skill measurement based on Joseph DeVito dimension, reliability obtained of 0.881 . The results of this study were obtained from the pearson $r$-test results of -0.167 and the significance value of 0.001. This indicates a negative correlation between the internet addictive with the interpersonal communication skill but in very low category.
\end{abstract}

Keywords: Internet addiction, interpersonal communication skill, adolescents.

\begin{abstract}
ABSTRAK
Penggunaan internet sudah sangat meluas dalam kehidupan masa kini, hampir setiap individu memiliki akses untuk menggunakan internet. Namun, pada batasan tertentu penggunaan internet yang seharusnya positif dapat berubah menjadi negatif karena adanya efek kecanduan. Pada penelitian-penelitian sebelumnya telah diperoleh hasil mengenai adanya komorbid efek candu internet dengan depresi, masalah sosial, maupun kecemasan. Penggunaan internet yang berlebihan dapat mempengaruhi kemampuan keterampilan komunikasi interpersonal seseorang. Sedangkan pada masa kini, komunikasi menjadi hal yang penting dalam kehidupan manusia, khususnya bagi para remaja yang masih pada tahap perkembangan. Penelitian ini bertujuan untuk mengetahui bagaimanakah hubungan antara internet adiktif dengan keterampilan komunikasi interpersonal pada remaja. Penelitian ini menggunakan metode kuantitatif. Subjek dalam penelitian ini berjumlah 400 remaja usia 15-19 tahun di wilayah Jakarta. Teknik sampling menggunakan teknik purposive sampling. Dalam penelitian ini internet adiktif diukur dengan menggunakan Internet Addiction Test yang dibawakan oleh Young, dengan reliabilitas sebesar 0.819 dan pengukuran keterampilan komunikasi interpersonal dengan menggunakan alat ukur keterampilan komunikasi interpersonal berdasarkan dimensi Joseph DeVito, reliabilitas yang diperoleh sebesar 0.881 . Hasil penelitian ini diperoleh nilai uji korelasi r pearson sebesar -0.167 dan nilai signifikansi 0.001 . Hal ini menunjukkan adanya korelasi negatif antara internet adiktif dengan keterampilan komunikasi interpersonal namun dalam kategori sangat rendah.
\end{abstract}

Kata Kunci: Internet adiktif, keterampilan komunikasi interpersonal, remaja.

\footnotetext{
*Korespondensi Penulis:

1)pradinatakusumo@ymail.com

2)djatmika@bundamulia.ac.id
} 
Versi Online: http://journal.ubm.ac.id/index.php/psibernetika DOI: 10.30813/psibernetika.v13i1.2312 Hasil Penelitian

\section{PENDAHULUAN}

Di Indonesia, pengguna media Internet pada tahun 2019 mencapai 171,17 juta jiwa atau 64,8 persen dari total 264 juta jiwa penduduk Indonesia, dimana pengguna terbanyak adalah remaja berusia 15-19 tahun. Dari data survey APJII (Asosiasi Penyedia Jasa Internet Indonesia) memperlihatkan bahwa pengguna internet terbesar berada di pulau Jawa sebanyak 16 persen, namun angka penggunaan internet di pulau Jawa dengan pulau lain relatif sama (APJII dalam Pratomo, 2019). Internet dapat membawakan segudang manfaat bagi penggunanya baik dalam bidang pendidikan sampai hiburan. Bisa dikatakan Internet merupakan penemuan yang sangat berpengaruh di dunia pada saat ini, dengan internet kita mampu menjelajah seluruh dunia, untuk mengaksesnya pun cukup mudah, tidak hanya dengan komputer saja, laptop, gadget, dan berbagai smartphone lainnya juga dapat digunakan untuk mengakses internet (Zaenudin, 2014).

Studi "Keamanan Penggunaan Media Digital pada Anak dan Remaja di Indonesia" yang dilakukan lembaga PBB, UNICEF, bersama para mitra, termasuk Kementerian Komunikasi dan Informatika dan Universitas Harvard, AS menelusuri aktivitas online dari sampel anak dan remaja yang melibatkan 400 responden berusia 10 sampai 19 tahun di seluruh Indonesia dan mewakili wilayah perkotaan dan pedesaan. Sebanyak 98 persen dari anak dan remaja mengaku tahu tentang internet dan 79,5 persen di antaranya adalah pengguna internet (Panji, 2014). Sisanya mengatakan tidak menggunakan internet dikarenakan tidak diizinkan orangtua atau tidak memiliki perangkat pendukung untuk mengakses internet. Internet sendiri bagi remaja, seringkali dimanfaatkan sebagai media untuk mencari informasi, untuk terhubung dengan teman (lama dan baru) dan untuk hiburan (Panji, 2014). Pencarian informasi yang dilakukan seringkali didorong oleh tugas-tugas sekolah, sedangkan penggunaan media sosial dan konten hiburan didorong oleh kebutuhan
Jurnal Psibernetika

Vol. 13 (No.1) : 20 -31. Th. 2020

p-ISSN: 1979-3707

e-ISSN: 2581-0871

pribadi. Penggunaan internet dapat dikatakan "sehat" ketika penggunaannya untuk tujuan yang jelas dengan jumlah kuantitas waktu yang wajar, dan tanpa merusak kenyamanan baik secara kognitif maupun perilaku. Sedangkan, penggunaan internet dikatakan "bermasalah" adalah ketika kondisi tersebut telah mempengaruhi pikiran menjadi maladaptif dan perilaku yang patologis atau menyimpang (Mustafa, 2011). Namun, di lain sisi internet juga seringkali dimanfaatkan untuk hal-hal yang negatif, misalnya cyber crime, perjudian, cybersex atau cyber porn. Banyak juga yang memanfaatkan internet sebagai alat untuk mengirim pesan (surat menyurat), chatting, dan juga bermain game online. Hal-hal menarik inilah yang menyebabkan seseorang menjadi betah berlama-lama untuk menggunakan internet, semakin bertambahnya waktu secara intensif dan terus menerus inilah yang dapat disebutkan sebagai kecanduan internet (internet addiction). Efek dari penggunaan internet sendiri cukup besar, bahkan dapat mengakibatkan depresi, oleh karena itu perlu diperhatikan waktu yang digunakan untuk berselancar dengan internet apakah sudah masuk kedalam zona kecanduan.

Studi terbaru Morrison (2010) menunjukkan bahwa 1,2 persen orang yang kecanduan internet cenderung mengalami depresi. Kesimpulan ini diambil berdasarkan survei yang dilakukan secara online terhadap 1.310 orang responden dengan usia 16-51 tahun. Peneliti menemukan bahwa sejumlah responden mempunyai dorongan tinggi untuk berinternet hingga menggeser kehidupan sosial di dunia nyata. Mereka lebih suka berkomunikasi lewat situs jejaring sosial atau chat room. Selain itu, para pecandu internet mulai kehilangan makna pertemanan karena menggantinya dengan teman-teman virtual di jejaring sosial. Hal ini mungkin mempengaruhi kesehatan mental mereka. Ia juga menambahkan, sosialisasi seharusnya dilakukan lewat kegiatan tatap muka, dan interaksi langsung merupakan salah satu faktor yang membuat mental kita selalu dalam keadaan sehat 
Versi Online: http://journal.ubm.ac.id/index.php/psibernetika DOI: 10.30813/psibernetika.v13i1.2312 Hasil Penelitian

karena bagaimanapun juga manusia adalah makhluk sosial (Corlett dalam Acandra, 2010).

Ningtyas (2012) menyebutkan
internet addiction adalah pemakaian
internet secara berlebihan yang ditandai
dengan gejala-gejala klinis kecanduan,
seperti keasyikkan dengan objek candu,
tidak memperdulikan dampak fisik maupun
psikologis pemakaian dan sebagainya.
Internet Addiction Disorder (IAD) atau
gangguan kecanduan internet meliputi
segala macam hal yang berhubungan
dengan internet seperti jejaring sosial, e-
mail, pornografi, judi online, game online,
chatting, dan lain-lain. Menurut Mustafa
(2011), internet adiktif adalah
ketidakmampuan individu untuk
mengontrol penggunaan internet, dimana akan menyebabkan gangguan pada aspek psikologis, sosial, sekolah, maupun pekerjaan. Internet adiktif juga berkomorbid dengan kecemasan sosial, kelainan seksual, perjudian, dan kecanduan lainnya, bahkan depresi. Internet adiktif juga seringkali dihubungkan dengan kurangnya kemampuan sosial (Cunningham \& Caldwell, 2010). Young (dalam Mustafa, 2011) mengkarakteristikkan pengguna internet dapat digolongkan adiktif jika pengguna tetap "aktif" selama 38 jam per minggu, sebagian besar dengan pesan teks, dan dapat mengganggu hubungan keluarga, teman, dan pekerjaan.

Menurut Papalia (2012), masa remaja merupakan periode dimana pencarian identitas diri. Erikson (dalam Papalia, 2012) menyatakan bahwa tugas utama dari remaja untuk menghadapi tahap krisis identitas atau kebingungan identitas, dengan itu maka remaja dapat bertumbuh menjadi dewasa yang unik, dengan pengertian yang baik mengenai diri dan nilai dari kehidupan sosial. Remaja diharapkan dapat mencapai hubungan baru dan yang lebih matang dengan teman sebaya baik pria maupun wanita, dan juga diharapkan mencapai kemandirian emosional, perilaku sosial yang bertanggung jawab. Salah satu kesulitan untuk mencapai hubungan baru yang lebih
Jurnal Psibernetika

Vol.13 (No.1) : 20 -31. Th. 2020

p-ISSN: 1979-3707

e-ISSN: 2581-0871

matang adalah melakukan komunikasi dengan orang lain seperti menyampaikan pikiran, pendapat, dan perasaannya (Purnomo, 2016). Keterampilan komunikasi interpersonal sendiri dapat diartikan sebagai keterampilan komunikasi antara orangorang secara tatap muka, memungkinkan setiap pesertanya menangkap reaksi orang lain secara langsung, baik secara verbal ataupun non-verbal sehingga dapat terjadi saling pengertian dan empati satu dengan lainnya (Noberta dalam Purnomo, 2016). Joseph De Vito (dalam Febriati, 2014) menyatakan bahwa komunikasi antarpribadi merupakan pengiriman pesan-pesan dari seseorang dan diterima oleh orang lain, atau juga sekelompok orang dengan efek dan umpan balik yang langsung atau dengan kata lain komunikasi antar pribadi sebenarnya merupakan suatu proses sosial. DeVito (2014), berpendapat bahwa komunikasi interpersonal dibagi menjadi 5 aspek, yaitu keterbukaan (openness), empati (emphaty), dukungan (supportiveness), positif (positiveness), dan kesamaan (equality). Pertama, keterbukaan adalah suatu keinginan untuk terbuka dalam menyatakan atau mengungkapkan informasi tentang diri sendiri dengan sewajarnya. Keterbukaan juga termasuk keinginan untuk mendengarkan secara terbuka dan merespon dengan baik informasi yang diberikan dari orang lain atau lawan bicara. Kedua, empati adalah suatu keadaan dimana kita memahami apa yang dirasakan oleh lain. Untuk berempati dengan orang lain adalah dengan cara merasakan perasaannya, melihat dunia sesuai dengan sudut pandang mereka, merasakan apa yang mereka rasakan. Empati juga akan membantu kita mengembangkan hubungan. Keiga, dukungan adalah pesan deskriptif menyatakan secara relatif objektif mengenai apa yang anda lihat dan rasakan, membuat orang lain merasa didukung. Keempat, karakteristik dari keefektifan interpersonal yang mempengaruhi sikap positif dan penggunaan pesan positif untuk mengekspresikan sikap dengan penerimaan dan persetujuan. Kelima, kesamaan yang berarti adanya pengakuan bahwa kedua 
Versi Online: http://journal.ubm.ac.id/index.php/psibernetika DOI: 10.30813/psibernetika.v13i1.2312 Hasil Penelitian

belah pihak adalah setara, tidak memandang adanya perbedaan latar belakang keluarga ataupun sikap oranglain terhadapnya.

Dalam masa perkembangannya remaja juga penting dalam mengembangkan identitas diri dan konsep diri yang positif, hal-hal ini dapat dicapai melalui interaksi yang signifikan dari anggota keluarga, teman, dan lainnya. Kemampuan dalam mengembangkan hubungan interpersonal dapat menjadi dasar efisiensi dalam mencapai hubungan sosial, pekerjaan, maupun ekonomi seseorang. Sebaliknya, jika saat hubungan tidak terjalin dengan baik dalam tahap ini, berbagai gangguan secara mental dan masalah adaptasi bisa muncul, misalnya depresi, kecemasan, agresivitas, maladaptif, dan sebagainya. Orang-orang yang tidak memiliki hubungan interpersonal yang baik di dunia nyata akan bergantung pada internet untuk berkomunikasi maupun untuk kebutuhan hiburan (Seo, 2009). Seo, Kang, and Yom (2009) juga mengemukakan bahwa berdasarkan hasil penelitian yang dilakukan mengenai internet adiktif dan hubungannya dengan masalah interpersonal pada remaja di Korea dengan partisipan sejumlah 676 yang termasuk anak sekolah menengah. Sebagian besar partisapan merupakan pengguna internet lebih dari 1 jam per hari dan penggunannya sebagian besar adalah untuk bermain game online diikuti dengan chatting. Diperoleh hasil penelitian bahwa terdapat korelasi positif antara internet adiktif dan masalah interpersonal pada remaja, hal ini menunjukkan bahwa semakin besar seorang remaja mengalami kecanduan internet maka semakin besar pula individu tersebut mengalami masalah sosial. Penelitian ini juga menunjukkan bahwa individu dengan internet adiktif memiliki tendensi untuk menghabiskan waktu sendiri lebih lama dan memiliki hubungan yang lebih jauh dengan teman dan keluarga. Hal inilah yang menjadi penyebab remaja untuk mendapatkan kebutuhan sosialnya dengan cara berhubungan di dunia maya, dibandingkan dengan kehidupan nyata. Dewi dan Trikusimaadi (2016) dalam penelitiannya
Jurnal Psibernetika

Vol.13 (No.1) : 20 -31. Th. 2020

p-ISSN: 1979-3707

e-ISSN: 2581-0871

menemukan kecanduan internet berkorelasi kuat terhadap karakter kerjasama mahasiswa yang membutuhkan kemampuan komunikasi.

Berdasarkan paparan di atas, pentingnya untuk meneliti hubungan adiksi internet terhadap keterampilan interpersonal remaja di Jakarta terutama pada usia pengguna internet yang tinggi di Indonesia karena belum adanya penelitian sebelumnya yang meninjau dalam konteks remaja sebagai pengguna internet serta secara spesifik karakteristik remaja dalam sampel penelitian ini adalah menggunakan internet lebih dari 5 jam per hari.

\section{METODE PENELITIAN}

Penelitian ini menggunakan metode kuantitatif, yaitu metode penelitian yang berdasarkan pengukuran variabel untuk partisipan individual atau subjek yang berisi nilai, biasanya dalam bentuk angka dan dimasukkan kedalam analisis statistikal untuk intisari dan interpretasi (Gravetter \& Forzano, 2012). Jenis penelitian ini adalah penelitian korelasional. Variabel dalam penelitian ini terdiri dari dua variabel, yaitu variabel bebas (Independent Variable) dan variabel terikat (Dependent Variable). Variabel bebas dalam penelitian ini adalah internet adiktif dan variabel terikat dalam penelitian ini adalah keterampilan komunikasi interpersonal.

Sampel dalam penelitian ini adalah remaja yang berdomisili di Jakarta dengan rentang usia 15-19 tahun dengan durasi penggunaan internet selama minimal 38 jam dalam seminggu atau lebih dari 5 jam dalam satu hari. Sampel dalam penelitian ini berjumlah 459 orang, 59 diantaranya merupakan sampel untuk uji coba dan 400 orang sebagai data penelitian. Teknik sampling yang digunakan dalam penelitian ini adalah Non Random Sampling dengan jenis purposive sampling yaitu cara pengambilan sampel yang mendasarkan pada ciri-ciri atau sifat-sifat tertentu yang diperkirakan mempunyai sangkut paut erat dengan ciri-ciri atau sifat-sifat yang ada 
Versi Online: http://journal.ubm.ac.id/index.php/psibernetika DOI: 10.30813/psibernetika.v13i1.2312

Hasil Penelitian

dalam populasi yang sudah diketahui sebelumnya (Narbuko \& Achmadi, 2008).

Pada penelitian ini, peneliti menggunakan dua alat ukur yaitu Internet Addiction Test dari Young dan alat ukur keterampilan komunikasi interpersonal yang mengacu pada aspek-aspek komunikasi interpersonal oleh DeVito yang disertai dengan empat alternatif jawaban yang terdiri dari Sangat Setuju (SS), Setuju (S), Tidak Setuju (TS), dan Sangat Tidak Setuju (STS) untuk kuesioner Keterampilan Komunikasi Interpersonal dan empat pilihan jawaban yaitu, Selalu, Sering, Kadang-Kadang, dan Tidak Pernah untuk kuesioner Internet Addiction Test. Penyebaran kedua alat ukur ini dilakukan dengan cara pembagian kuesioner secara langsung kepada responden dan pembagian kuesioner secara tidak langsung, yaitu dengan menggunakan google form.

Alat ukur Internet Addiction Test (IAT) diadaptasi dari alat ukur yang dikembangkan oleh Kimberly S. Young yang terdiri dari 20 aitem. Berdasarkan studi mengenai IAT ditemukan bahwa kuesioner IAT memiliki cronbach's alpha sebesar 0.889 (Frangos, 2012). IAT terdiri dari tiga indikator: Time Management \& performance yaitu suatu keadaan dimana seseorang telah melewati batasan penggunaan internet dan mengalami kesulitan saat berusaha menghindari internet; Withdrawal \& Social Problems yaitu suatu keadaan dimana sudah mempengaruhi penggunaan internet yang berlebihan dan adanya kegagalan dalam mengontrol atau mengurangi jumlah waktu yang digunakan untuk online; dan Reality Substitute yaitu suatu keadaan dimana pengguna internet lebih menganggap lingkungan online sebagai hubungan yang nyata dan terlalu bergantung pada internet untuk meringankan suatu masalah pada kehidupan nyata.

Selanjutnya, alat ukur Keterampilan Komunikasi Interpersonal yang dikembangkan oleh peneliti dengan berdasarkan aspek komunikasi interpersonal DeVito yang dibagi menjadi 5 aspek, yaitu keterbukaan (openness), empati
Jurnal Psibernetika

Vol. 13 (No.1) : 20 -31. Th. 2020

p-ISSN: 1979-3707

e-ISSN: 2581-0871

(emphaty), dukungan (supportiveness), positif (positiveness), dan kesamaan (equality). Alat ukur ini terdiri dari 25 aitem dengan 14 aitem favorable dan 11 aitem unfavorable.

Batasan yang digunakan untuk mengambil kesimpulan aitem valid dan tidak valid adalah dengan membandingkan nilai aitem corrected item-total correlation dengan $\mathrm{r}$ tabel product moment pearson. Diperoleh $r$ tabel $=0.2569$ dimana aitem akan dikatakan valid bila nilai aitem corrected item-total correlation lebih besar atau sama dengan $r$ tabel dan bila sebaliknya aitem dinyatakan tidak valid atau gugur. Menurut Thixman \& Tileng (2016) reliabilitas suatu alat ukur dapat dikatakan baik jika memiliki nilai $\alpha<0.9$ dan $\alpha \geq 0.8(0.8 \leq \alpha<0.9)$. Hasil uji coba alat ukur IAT diperoleh nilai koefisien alpha Cronbach sebesar 0.819 dengan rentang validitas 0.280 sampai 0.621 . berdasarkan hasil uji coba terakhir diperoleh sebanyak 16 aitem valid. Hasil uji coba pertama alat ukur komunikasi interpersonal, diperoleh nilai koefisien alpha cronbach sebesar 0.881 dengan rentang validitas 0.264 sampai 0.631 . Hasil uji coba terakhir diperoleh sebanyak 25 aitem valid.

Teknik analisa data yang digunakan dalam penelitian ini menggunakan teknik analisis uji asumsi dengan one-sample kolmogorov-smirnov test, penormaan kategori dengan norma persentil dan uji korelasi dengan korelasi Pearson.

\section{HASIL DAN PEMBAHASAN}

Tabel 1. Uji Asumsi One Sample K-S

\begin{tabular}{lcc}
\hline & $\begin{array}{c}\text { Internet } \\
\text { Adiktif }\end{array}$ & $\begin{array}{c}\text { Keterampilan } \\
\text { Komunikasi } \\
\text { Interpersonal }\end{array}$ \\
\hline $\begin{array}{l}\text { Kolmogorov- } \\
\text { Smirnov Z }\end{array}$ & 1.228 & 0.912 \\
$\begin{array}{l}\text { Asymp. Sig. } \\
\text { (2-tailed) }\end{array}$ & 0.098 & 0.376 \\
\hline
\end{tabular}


Versi Online: http://journal.ubm.ac.id/index.php/psibernetika DOI: 10.30813/psibernetika.v13i1.2312

Hasil Penelitian

Dalam penelitian ini, peneliti melakukan uji normalitas untuk melihat hubungan antar variabel apakah bersifat parametric atau non-parametric. Pada tahap ini peneliti melakukan uji normalitas pada keseluruhan responden data penelitian yang berjumlah 400 orang. Diperoleh hasil uji asumsi yang menunjukkan bahwa data terdistribusi normal baik pada sampel internet adiktif maupun sampel keterampilan komunikasi interpersonal. Hal tersebut dibuktikan dengan hasil uji asumsi dengan menggunakan one-sample kolmogorov-smirnov test. Pada alat ukur internet adiktif menunjukkan nilai signifikansi sebesar 0.098, nilai tersebut berada diatas nilai signifikansi 0.05 ( $p>0.05$ ). Sama halnya pada alat ukur keterampilan komunikasi interpersonal dengan nilai signifikansi sebesar 0.376 yang juga lebih besar atau berada diatas nilai signifikansi 0.05 ( $p>0.05)$.

Tabel 2. Uji Korelasi

\begin{tabular}{|c|c|c|c|}
\hline & & $\begin{array}{l}\text { Internet } \\
\text { Adiktif }\end{array}$ & $\begin{array}{l}\text { Keterampilan } \\
\text { Komunikasi } \\
\text { Interpersonal }\end{array}$ \\
\hline \multirow{3}{*}{$\begin{array}{l}\text { Internet } \\
\text { Adiktif }\end{array}$} & $\mathrm{r}$ & 1 & -0.167 \\
\hline & Sig. & & 0.001 \\
\hline & $\mathrm{N}$ & 400 & 400 \\
\hline
\end{tabular}

Hasil uji korelasi pada penelitian ini, diperoleh dengan melakukan pengujian hubungan antara dua variabel dengan menggunakan korelasi pearson pada program SPSS 16. Peneliti menggunakan korelasi pearson karena data terdistribusi normal. Berdasarkan data uji korelasi, diperoleh nilai $r$ pearson sebesar -0.167 dengan nilai signifikansi (p) sebesar 0.001 dimana $\mathrm{p}<0.01$ yang artinya H0: ditolak dan $\mathrm{H} 1$ : diterima. Hal ini menunjukkan adanya hubungan yang sangat rendah antara internet adiktif dengan keterampilan komunikasi interpersonal. Ditunjukkan bahwa $\mathrm{r}<0$ dan $\mathrm{r}>-1$ yang berarti hubungan antara kedua variabel merupakan korelasi negatif $(-1<\mathrm{r}<0)$ dan signifikan,
Jurnal Psibernetika

Vol. 13 (No.1) : 20 -31. Th. 2020

p-ISSN: 1979-3707

e-ISSN: 2581-0871

artinya ketika variabel $X$ naik maka variabel $\mathrm{Y}$ akan turun atau semakin tinggi tingkat kecanduan internet maka akan semakin rendah tingkat keterampilan komunikasi interpersonal maupun sebaliknya, semakin tinggi tingkat keterampilan komunikasi interpersonal maka semakin rendah tingkat kecanduan internet.

Tabel 3. Uji Korelasi per Dimensi

\begin{tabular}{|c|c|c|c|}
\hline Dimensi & $\mathbf{r}$ & $\mathbf{p}$ & $\begin{array}{c}\text { Kekuatan } \\
\text { Korelasi }\end{array}$ \\
\hline $\begin{array}{l}\text { Time } \\
\text { Management } \\
\& \\
\text { Performance }\end{array}$ & -0.042 & 0.398 & $\begin{array}{c}\text { Tidak } \\
\text { Ada } \\
\text { Korelasi }\end{array}$ \\
\hline $\begin{array}{l}\text { Withdrawal } \\
\& \text { Social } \\
\text { Problems }\end{array}$ & -0.310 & 0.000 & $\begin{array}{l}\text { Korelasi } \\
\text { Rendah }\end{array}$ \\
\hline $\begin{array}{l}\text { Reality } \\
\text { Substitute }\end{array}$ & 0.052 & 0.296 & $\begin{array}{c}\text { Tidak } \\
\text { Ada } \\
\text { Korelasi }\end{array}$ \\
\hline
\end{tabular}

Berdasarakan tabel diatas dapat terlihat bahwa pada dimensi Withdrawal \& Social Problems diperoleh nilai $\mathrm{r}$ pearson sebesar -0.310 dengan signifikansi (p) sebesar 0.000 dimana $p<0.05$ yang menunjukkan bahwa terdapat hubungan antara dimensi Withdrawal \& Social Problems dengan keterampilan komunikasi interpersonal. Sedangkan, dua dimensi lainnya yaitu Time Management \& Performance dan Reality Substitute menunjukkan tidak ada hubungan antara kedua dimensi tersebut dengan keterampilan komunikasi interpersonal. Hal ini ditunjukkan berdasarkan dimensi Time Management \& Performance yang memperoleh nilai $\mathrm{r}$ pearson sebesar -0.042 dengan signifikansi (p) sebesar 0.398 dimana $\mathrm{p}>0.05$ dan dimensi Reality Substitute yang memperoleh nilai $\mathrm{r}$ pearson sebesar 0.052 dengan signifikansi (p) sebesar 0.296.

Pembahasan

Hasil dari penelitian ini menunjukkan adanya korelasi negatif antara 
Versi Online: http://journal.ubm.ac.id/index.php/psibernetika DOI: 10.30813/psibernetika.v13i1.2312 Hasil Penelitian

variabel internet adiktif dengan variabel keterampilan komunikasi interpersonal. Hal ini terlihat dari nilai koefisien $\mathrm{r}$ pearson sebesar -0.167 dengan nilai signifikansi $(p)$ sebesar 0.001 dimana $r<0$ dan $r>-1$ yang berarti hubungan antara kedua variabel merupakan korelasi negatif $(-1<\mathrm{r}<0)$ dan signifikan $\mathrm{p}<0.01$, Ho ditolak yang berarti ada hubungan antara internet adiktif dengan keterampilan komunikasi interpersonal. Korelasi negatif artinya ketika variabel $\mathrm{X}$ naik maka variabel $\mathrm{Y}$ akan turun atau semakin tinggi tingkat kecanduan internet maka akan semakin rendah tingkat keterampilan komunikasi interpersonal begitu pula sebaliknya. Besar $\mathrm{r}$ pearson yang diperoleh menunjukkan bahwa antara variabel X dan Y memiliki korelasi dengan tingkatan sangat rendah. Pada penelitian sebelumnya, Nurmandia (2013) melakukan penelitian mengenai kecanduan jejaring sosial dan hubungannya dengan kemampuan sosial. Dari penelitian tersebut diperoleh hasil bahwa adanya hubungan negatif antara kemampuan sosial dan kecanduan jejaring sosial. Hal ini menunjukkan bahwa, remaja yang mempunyai kemampuan sosialisasi rendah, maka semakin sering remaja tersebut menggunakan jejaring sosial. Penelitian ini sejalan adanya dengan kecanduan internet adiktif dan hubungannya dengan keterampilan komunikasi interpersonal. Karena menurut Joseph De Vito (dalam Febriati, 2014) kemampuan komunikasi interpersonal sesungguhnya adalah kemampuan sosial dan dari hal ini terlihat bahwa efek dari kecanduan memberikan dampak pada kemampuan sosial seseorang. Seo, Kang, \& Yom (2009) dalam penelitiannya juga menyatakan bahwa terdapat korelasi positif antara internet adiktif dengan masalah sosial pada remaja. Penelitian ini juga menunjukkan bahwa remaja dengan risiko internet adiktif lebih mungkin untuk memiliki masalah interpersonal. Secara lebih spesifik, pengguna internet dengan tingkat tinggi memiliki tingkat yang lebih tinggi pula akan perilaku asosial, ketidakpercayaan kepada orang lain, tidak peka, dan mudah
Jurnal Psibernetika

Vol. 13 (No.1) : 20 -31. Th. 2020

p-ISSN: 1979-3707

e-ISSN: 2581-0871

tersinggung. Hal ini menunjukkan bahwa penelitian ini juga menggambarkan hal yang sama dengan penelitian sebelumnya dimana individu dengan internet adiktif akan memiliki masalah mengenai kemampuan sosialnya yang juga menggambarkan rendahnya keterampilan komunikasi interpersonal yang dimiliki.

Selanjutnya dilakukan uji korelasi antara dimensi internet adiktif dengan keterampilan komunikasi interpersonal. Pada dimensi Time Management \& Performance diperoleh nilai $\mathrm{r}$ pearson sebesar -0.042 dengan signifikansi (p) sebesar 0.398 dimana $p>0.05$ hal ini menunjukkan bahwa tidak adanya korelasi antara dimensi Time Management \& Performance dengan keterampilan komunikasi interpersonal. Hasil korelasi ini menunjukkan bahwa sebenarnya ketidakmampuan seseorang dalam mengontrol waktu online nya belum tentu akan mempengaruhi keterampilan komunikasi interpersonalnya. Hal ini berkaitan pada self control individu, menurut Andaryani (2013) individu yang memiliki self control yang tinggi mampu mengarahkan dirinya dalam mengatur perilaku menggunakan internet. Berdasarkan norma Time Management \& Performance diperoleh hasil bahwa responden pada dimensi ini tergolong rendah, yang berarti responden pada penelitian ini memiliki pengelolaan waktu yang tergolong baik. Faktor lainnya juga dapat disebabkan oleh faktor individu, dimana individu yang sudah memiliki keterampilan komunikasi interpersonal yang baik, tidak akan dipengaruhi oleh penggunaan internet baik dalam kapasitas tinggi ataupun rendah. Menurut Wood (2013) komunikasi interpersonal dapat dipengaruhi oleh situasi, budaya maupun latar belakang secara personal. Sehingga kita tidak bisa menggabungkan seluruh sistem untuk memahami komunikasi interpersonal, namun kita harus memahami bahwa seluruh sistem tersebut saling berkaitan.

Pada dimensi Withdrawal \& Social Problems diperoleh nilai r pearson sebesar - 
Versi Online: http://journal.ubm.ac.id/index.php/psibernetika DOI: 10.30813/psibernetika.v13i1.2312 Hasil Penelitian

0.310 dengan signifikansi (p) sebesar 0.000 dimana $\mathrm{p}<0.05$ yang berarti adanya hubungan antara dimensi Withdrawal \& Social Problems dengan keterampilan komunikasi interpersonal dan memiliki korelasi negatif yang artinya semakin seseorang memiliki masalah sosial atau menarik diri dari lingkungan maka akan semakin rendah pula keterampilan komunikasi interpersonalnya. Menurut Goldberg, salah satu gejala kecanduan internet adiktif adalah munculnya gejala penarikan diri yang ditandai dengan adanya perasaan marah, tegang, atau depresi ketika internet tidak dapat diakses dengan berbagai macam alasan dan hal ini mengakibatkan interaksi dengan lingkungannya juga akan berkurang (Nurmandia, 2013). Selain itu, Dewiratri (2014) dalam penelitiannya juga mengemukakan bahwa pecandu internet biasanya akan membuat internet menjadi suatu prioritas dan lebih penting dari keluarga, teman, dan bahkan pekerjaan sekalipun yang pada akhirnya akan menyebabkan gangguan pada kehidupan sosial baik dari segi kualitas maupun kuantitas.

Pada dimensi Reality Substitude diperoleh nilai $\mathrm{r}$ pearson sebesar 0.052 dengan signifikansi (p) sebesar 0.296 dimana $\mathrm{p}>0.05$ yang berarti dimensi Reality Substitude tidak memiliki korelasi dengan keterampilan komunikasi interpersonal. Reality substitude adalah suatu keadaan dimana seseorang lebih menganggap lingkungan online sebagai hubungan yang nyata dan terlalu bergantung pada internet untuk meringankan masalah pada kehidupan nyata. Wood (2013) menyatakan kebudayaan mempunyai berbagai macam cara untuk membuat penekanan makna komunikasi. Dalam kebudayaan yang memiliki tradisi masyarakat kolektif, pemahamaannya dapat menjadi landasan dalam berkomunikasi dan cenderung berkomunikasi dalam tingkatan relasi, hal ini juga yang menyebabkan bahwa masyarakat kolektif seperti di Indonesia lebih mempunyai sikap saling bergantungan. Hal ini berkaitan dengan
Jurnal Psibernetika

Vol.13 (No.1) : 20 -31. Th. 2020

p-ISSN: 1979-3707

e-ISSN: 2581-0871

partisipan dalam penelitian ini memiliki jumlah terbanyak pada kategori sangat rendah dengan jumlah 146 orang. Sehingga dapat dikatakan bahwa sebagian besar responden tidak terlalu bergantung pada internet terutama untuk meringankan masalah atau mencari ketenangan. Hal ini menjelaskan bahwa masih terdapat faktor lain seperti budaya yang dapat mempengaruhi para responden dalam bertindak, sehingga tidak sepenuhnya seluruh masalah dilimpahkan pada internet.

Jika dilihat dari pembuatan norma per dimensi, variabel internet adiktif pada setiap dimensinya di penelitian ini tergolong kategori rendah. Pada dimensi withdrawal \& Social Problems diperoleh jumlah responden terbanyak pada kategori rendah yaitu sebanyak 208 responden dengan persentase $52 \%$. Pada dimensi Time Management \& Performance diperoleh jumlah responden terbanyak pada kategori rendah yaitu sebanyak 216 responden dengan persentase $54 \%$ dan pada dimensi reality substitude diperoleh jumlah responden terbanyak juga pada kategori rendah yaitu sebanyak 226 responden dengan persentase $56.5 \%$. Berdasarkan data tersebut, dapat dilihat bahwa walaupun pengambilan sampel sudah mengkarakteristikkan orang yang menggunakan internet lebih dari 5 jam atau minimal 38 jam dalam satu minggu sesuai dengan karakteristik dari Young (2004), ternyata hal tersebut belum tentu menggambarkan bahwa sampel tersebut merupakan individu dengan kecanduan internet dengan kategori tinggi.

$$
\text { Pada dimensi keterampilan }
$$

komunikasi interpersonal didapatkan hasil bahwa terdapat dua dimensi yang tergolong rendah yaitu dimensi Positiveness \& Equality. Jumlah subjek kategori rendah pada dimensi Positiveness mencapai 219 responden dengan persentase $54.7 \%$ dan dimensi Equality sebanyak 210 responden dengan persentase $52.5 \%$. Menurut DeVito (2014) salah satu tujuan dari komunikasi interpersonal adalah untuk bermain, dalam keseharian kita pasti akan berbicara dengan teman mengenai berbagai macam hal, baik 
Versi Online: http://journal.ubm.ac.id/index.php/psibernetika DOI: 10.30813/psibernetika.v13i1.2312

Hasil Penelitian

itu tentang olahraga, berita, candaan, bercerita atau juga game. Hal tersebut juga dapat menyebabkan tingkat kesamaan para responden juga sebenarnya bisa tinggi atau rendah, terutama jika terhadap lawan bicara yang memiliki kesamaan baik dalam hobi, komunitas dan lainnya. Jika sesama pemain game online saling bertemu, maka tingkat komunikasi yang terjadi bisa tergolong tinggi karena adanya kesamaan juga dengan sesama komunikan sehingga terjadi penerimaan, namun jika bertolak belakang, misalkan pemain game online dengan orangtua, maka akan tercipta komunikasi yang berbeda pula. Jika individu dengan tingkat kecanduan internet tinggi dan memiliki teman bermain yang serupa maka akan terjalin komunikasi yang baik antara keduanya karena masih dalam satu konteks yang sama.

Pada dimensi Positiveness, tinggi dan rendahnya tingkat keterampilan komunikasi seseorang dapat dipengaruhi juga oleh penggunaan kata yang kurang tepat (DeVito, 2007), sebagai contoh terdapat sebuah pernyataan negatif "rambut kamu terlihat sangat berantakan kalau panjang", seharusnya dapat disampaikan dengan positif seperti "menurut saya, kamu lebih bagus jika punya rambut pendek". Perbedaan penggunaan kata positif sangat penting bagi terbentuknya suatu hubungan interpersonal. Jika dilihat dari jawaban responden yang cenderung rendah pada dimensi ini, dapat disimpulkan bahwa sebagian besar responden merasa bahwa dirinya kurang mampu menerima adanya perbedaan pendapat dengan individu lain. Pada penelitian sebelumnya, ditemukan bahwa ada pengaruh komunikasi positif dalam keluarga dan guru terhadap perilaku asertif pada siswa, perilaku asertif dapat ditunjukkan melalui sikap seseorang yang lebih percaya diri, dan mendapatkan rasa hormat dari orang lain melalui komunikasi secara langsung, terbuka, dan jujur sehingga dapat menumbuhkan hubungan sosial yang baik. Dengan kata lain semakin tinggi tingkat komunikasi interpersonal keluarga atau guru, semakin pula tingkat asertif pada siswa (Ardianto, 2016). Hal ini
Jurnal Psibernetika

Vol. 13 (No.1) : 20 -31. Th. 2020

p-ISSN: 1979-3707

e-ISSN: 2581-0871

membuktikan bahwa gaya komunikasi dari pihak keluarga dan guru di sekolah juga berpengaruh pada tingkat asertif seorang siswa yang akhirnya dapat berpengaruh pada hubungan sosialnya juga.

\begin{tabular}{lrr}
\multicolumn{1}{c}{ Tiga dimensi lainnya } & yaitu \\
Empathy, dan Openness, & dan \\
Supportiveness pada penelitian & ini
\end{tabular} tergolong tinggi. Pada dimensi Empathy jumlah responden terbesar berada pada kategori tinggi yaitu sebanyak 227 responden dengan persentase $56.75 \%$. Pada dimensi Openness jumlah responden kategori tinggi sebanyak 254 responden dengan persentase $63.5 \%$. Pada dimensi supportiveness mencapai 234 responden dengan persentase sebesar 58.5\%. Empati menurut menurut DeVito (2014) adalah suatu keadaan dimana kita memahami apa yang dirasakan oleh lain. Untuk berempati dengan orang lain adalah dengan cara merasakan perasaannya, melihat dunia sesuai dengan sudut pandang mereka, merasakan apa yang mereka rasakan. Empati juga akan membantu kita mengembangkan suatu hubungan dengan orang lain. Dalam sebuah penelitian yang dibawakan oleh McCullough, Worthington, dan Rachal (1997) menyatakan bahwa empati kepada seseorang akan membawa kita untuk lebih mudah memaafkan seseorang. Empati dalam suatu hubungan interpersonal juga dapat didasari oleh waktu kebersamaan yang panjang (Angraini, 2014). Jadi, empati sebenarnya sudah dapat terbentuk sejak lama terutama pada hubungan yang sudah lebih dekat misalnya teman atau sahabat sehingga peneliti tidak dapat mengatakan seseorang memiliki empati yang tinggi atau rendah hanya berdasarkan keterkaitannya dengan internet adiktif.

Sebuah studi mengenai MMOs (Online Role Playing Games) yang dibawakan oleh Parks \& Roberts (1998) ternyata banyak juga hubungan baik yang terbentuk melalui permainan game online, sebagian besar dari pemain membentuk pertemanan dan bahkan mendapatkan pasangan (hubungan romantis). Sebagian orang juga ternyata khusus menggunakan 
Versi Online: http://journal.ubm.ac.id/index.php/psibernetika DOI: 10.30813/psibernetika.v13i1.2312

Hasil Penelitian

internet sebagai alat untuk berinteraksi atau membentuk hubungan baru dengan cara telepon, foto, dan juga pertemuan secara nyata. Ditemukan juga bahwa wanita cenderung lebih mungkin untuk membentuk suatu hubungan baru di internet dibandingkan dengan pria (DeVito, 2007). Berdasarkan penelitian tersebut dapat dilihat ternyata para pengguna internet atau pemain game online juga banyak menjalin hubungan baru yang berarti memiliki sikap keterbukaan dengan orang lain sehingga dapat menjalin hubungan baru walaupun melalui game, atau media lainnya. Pada dimensi Supportiveness hanya tersisa 3 aitem yang berasal dari indikator menghindari tuduhan atau tidak menyalahkan dan menghindari istilah negatif. Diperoleh hasil bahwa sebagian besar responden menjawab dengan skor sangat tinggi, yang artinya sebagian besar para responden dalam penelitian ini mempunyai sikap suportif dalam berinteraksi dimana sebagian besar responden lebih menghindari penggunaan istilah negatif dan cenderung tidak mudah menyalahkan orang lain.

Diperoleh juga hasil penelitian bahwa terdapat perbedaan antara sampel pria dan wanita dalam sampel internet adiktif. Jika dilihat dari penyebaran pengguna internet di Indonesia, data survei yang dilakukan Asosiasi Penyelenggara Internet Indonesia (2014) menyatakan bahwa ternyata pengguna internet di Indonesia didominasi oleh kaum perempuan dan mayoritas adalah yang berdomisili didaerah urban. Di Jakarta sendiri perbandingan pengguna internet antara pria dan wanita menunjukkan komposisi yang tidak yang seimbang, yaitu perempuan sebesar $73 \%$ dan sementara pengguna interent berjenis kelamin laki-laki hanya sebesar 23\%. Selain itu penelitian yang dibawakan oleh Park \& Roberts (1998) menunjukkan bahwa wanita cenderung lebih mungkin untuk membentuk suatu hubungan baru di internet dibandingkan dengan pria (DeVito, 2007).
Jurnal Psibernetika

Vol.13 (No.1) : 20 -31. Th. 2020

p-ISSN: 1979-3707

e-ISSN: 2581-0871

\section{SIMPULAN}

Berdasarkan hasil penelitian, dapat diambil kesimpulan bahwa penelitian ini memiliki korelasi negatif antara variabel internet adiktif dengan variabel keterampilan komunikasi interpersonal. hubungan antara dua variabel saling bertolak belakang yaitu semakin tinggi tingkat internet adiktif maka semakin rendah tingkat keterampilan komunikasi interpersonal atau sebaliknya.

Bagi penelitian selanjutnya, sebaiknya memperbaharui kriteria kecanduan internet dan lebih mempertimbangkan karakteristik sampel dan populasi pada wilayah yang lebih spesifik untuk melaksanakan penelitian. Misalkan karakteristik sampel yang dipakai hanya partisipan yang termasuk pada kategori penggunaan internet tinggi atau termasuk dalam kategori tertentu misalnya cybersexual, cyber relationship, net compulsion dan lainnya. Selain itu, juga memperhatikan pemilihan wilayah pengambilan sampel yang lebih spesifik, misalkan di warnet atau sekolah tertentu sehingga mendapatkan perbandingan yang lebih baik lagi. Diharapkan peneliti selanjutnya dapat mengembangkan penelitian variabel internet adiktif dengan variabel lainnya misalnya dengan self control, rasa percaya diri, loneliness.

\section{DAFTAR PUSTAKA}

Acandra. (2010). Pecandu internet adalah orang stres. Diakses pada 13 Maret 2017 dari http://nasional.kompas. com/read/2010/02/03/17115665/penc andu.internet.adalah.orang.stres

Andaryani, D. (2013). Perbedaan Tingkat Self Control pada Remaja Laki-Laki dan Remaja Perempuan yang Kecanduan Internet. Journal Psikologi Pendidikan dan Perkembangan, 2(3), 206-214

Ardianto. (2016). Pengaruh Komunikasi Positif dalam Keluarga dan Komunikasi Interpersonal Guru terhadap Perilaku Asertif Siswa. 
Versi Online: http://journal.ubm.ac.id/index.php/psibernetika DOI: 10.30813/psibernetika.v13i1.2312

Hasil Penelitian

Journal of Islamic Education Policy, 1(2), 82-98.

Cunningham \& Caldwell. (2010). Internet Addiction and Students: Implications for School Counselor. Diakses pada 15 Maret dari https://www.counseling.org/Resource s/Library/VISTAS/2010-VOnline/Article_61.pdf

DeVito, J. A. (2007). The Interpersonal Communication Book : Eleventh Edition. United States of America: Pearson Education, Inc.

DeVito, J. A. (2014). The Interpersonal Communication Book : Thirteenth Edition. United States of America: Pearson Education, Inc.

Dewi, N., \& Trikusumaadi, S. K. (2016). Bahaya kecanduan internet dan kecemasan komunikasi terhadap karakter kerja sama pada mahasiswa. Jurnal Psikologi, 43(3) , 220-230.

Dewiratri, T., Karini. S., \& Machmuroch. (2014). Hubungan Antara Kecanduan Internet dan Depresi pada Mahasiswa Pengguna Warnet di Kelurahan Jebres Surakarta. Jurnal Psikologi 3(2), 75-84. Diakses dari http://candrajiwa.psikologi.fk.uns.ac.i d/index.php/candrajiwa/article/view/ 80

Febriati, A. A. (2014). Efektivitas Komunikasi Antar Pribadi Guru dan Siswa dalam Mencegah Kenakalan Siswa di SMA Negeri 1 Kota Bontang. Jurnal Komunikasi, 2(4), 287-296.

Gravetter, F., \& Forzano, L. A. (2012). Research Method for The Behavioral Science: International Edition. Canada: Wadsworth, Cengage Learning.

Jamaludin. (2015). Perempuan Masih jadi Jagoan Pengguna Internet. Diakses pada 13 Juni 2017 dari https://www.merdeka.com/teknologi/ perempuan-masih-jadi-jagoanpengguna-internet.html

Morrison, C. (2010). Excessive Internet Use is Linked to Depression. Diakses pada 13 Juni 2017 dari
Jurnal Psibernetika

Vol.13 (No.1) : 20 -31. Th. 2020

p-ISSN: 1979-3707

e-ISSN: 2581-0871

https://www.leeds.ac.uk/news/article/ $707 /$

Mustafa. (2011). Internet Addiction and Psychopatology. The Turkish Online Journal of Educational Technology $10(1)$.

Narbuko, C., \& Achmadi, H. (2008). Metodologi Penelitian. Jakarta: PT Bumi Aksara.

Ningtyas, S. D. W. (2012). Hubungan Antara Self Control dengan Internet Addiction pada Mahasiswa. Educational psychology journal, EPJ 1(1) (2012).

Nurmandia, H., Wigati, D., \& Luluk, M. (2013). Hubungan antara Kemampuan Sosialisasi dengan Kecanduan Jejaring Sosial. Jurnal Penelitian Psikologi, 4(2), 107-119.

Panji, A. (2014). Hasil Survei Penggunaan Internet Remaja Indonesia. Diakses pada 13 Maret 2017 dari http://tekno.kompas.com/read/2014/0 2/19/

Papalia, D. E., \& Feldman, R. D. (2012). Experience Human Development Twelfth Edition. America: McGrawHill.

Purnomo \& Harmiyanto. (2016). Hubungan Keterampilan Komunikasi Interpersonal dan Kepercayaan Diri Siswa Kelas X SMAN 1 Garum Kabupaten Blitar. Jurnal Kajian Bimbingan dan Konseling 1(2), 5559.

Seo, M., Kang \& Yom. (2009). Internet Addiction and Interpersonal Problems in Korean Adolescents. Computers, Informatics, Nursing, 27(4), 226-233. Diakses dari https://www.ncbi.nlm.nih.gov/pubme d/19574748

Thixman \& Tileng. (2016). Analisis Pengaruh Usability, Reputasi dan Keamanan Terhadap Kepercayaan Masyarakat dalam Bertransaksi Menggunakan E-Money di Indonesia. Jurnal Teknologi dan Informasi 14(1), 1-103. 
Wood, J. T. (2013). Komunikasi Interpersonal Interaksi Keseharian Edisi 6. Jakarta: Salemba Humanika.

Young, K. S. (2004). Internet Addiction : A New Clinical Phenomenon and Its Consequences. American Behavioral Scientist 48(4), 402-415.

Zaenudin, N. (2014). 10 Manfaat Penggunaan Internet Secara Umum. Diakses pada 13 Maret 2017, dari http://www.skipnesia.com/2014/06/1 0-manfaat-internet-secaraumum.html. 